\title{
El motivo del bodegón policial
}

\author{
Jordi Balló, Alan Salvadó y Eduard Cairol \\ Universidad Pompeu Fabra \\ jordi.ballo@upf.edu; alan.salvado@upf.edu; eduard.cairol@upf.edu
}

RESUMEN: Este artículo analiza una forma de transmisión iconográfica que se origina en una fuente artística del pasado, el bodegón manierista y barroco, que es readaptado y reformulado por las fuerzas de seguridad para transmitir un mensaje comunicativo de gran impacto: los objetos decomisados en una redada policial son presentados con una forma artística, que llamamos «bodegón policial», que incita inmediatamente al sentido de culpabilidad. Esta práctica sistemática de los diversos cuerpos policiales españoles (Guardia Civil, Policía Nacional, Mossos d'Esquadra, Ertzaintza) nos presenta un método de utilización de un motivo iconográfico como forma comunicativa de un poder de Estado. Este artículo sintetiza algunos de los resultados del proyecto de investigación MOVEP (Los motivos visuales en la esfera pública. Producción y circulación de imágenes del poder en España, 2011-2017), con referencia CSO2017-88876-P, que tiene como objetivo principal analizar la recurrencia, producción y circulación de motivos específicos relacionados con la representación del poder en imágenes aparecidas en la prensa, los medios digitales, el cine y la televisión.

PALABRAS CLAVE: Iconografía; Bodegón; Bodegón policial; Iconología; Poder.

\section{The Motif of the Police Still Life}

ABSTRACT: This article analyzes a form of iconographic transmission that originates from artistic sources of the past, the Mannerist and Baroque still lifes, which is readjusted and reformulated by the security forces to convey a communicative message of significant impact: the confiscated objects in a police raid are presented in an art form we call "police still life", that immediately incites the sense of guilt. This systematic practice of various Spanish police forces (Civil Guard, National Police, Mossos d'Esquadra, Ertzaintza) presents a method of using an iconographic motif as a communicative form of state power. This article summarizes some of the results of the research project MOVEP (The visual motifs in the public sphere. Production and circulation of images of power in Spain, 2011-2017), with reference CSO2017-88876-P, whose main objective is to analyze the recurrence, production, and circulation of specific motifs related to the representation of power in images appearing in the press, digital media, cinema, and television.

KEYWORDS: Iconography; Still Life; Police Still Life; Iconology; Power.

Recibido: 28 de febrero de 2020 / Aceptado: 21 de mayo de 2020.

\section{Introducción}

En el actual contexto de proliferación y sobreabundancia de imágenes, determinados dispositivos de puesta en escena producidos por el poder se popularizan construyendo un relato visual que influye en la percepción que la sociedad tiene sobre algunas problemáticas político-sociales. En el caso de las fuerzas de seguridad, los departamentos de comunicación de la mayoría de las policías del mundo controlan al detalle las imágenes que producen y distribuyen a los medios. Esta voluntad de control del sentido de la imagen creada desde la propia institución armada no ha hecho más que crecer en los últimos tiempos, hasta el punto de que son los cuerpos policiales quienes graban sus acciones con cámaras propias que documentan las operaciones más diversas, como las entradas a los domicilios de sospechosos, el registro de las manifes-

Cómo citar este artículo: BALLÓ, Jordi, SALVADÓ, Alan y CAIROL, Eduard, «El motivo del bodegón policial», Boletín de Arte-UMA, n. ${ }^{\circ} 41$, Departamento de Historia del Arte, Universidad de Málaga, 2020, pp. 59-70, ISSN: 0211-8483, e-ISSN: 2695-415X, DOI: http://dx.doi.org/10.24310/BoLArte.2020.v41i.8144 
taciones civiles o los decomisos de todo tipo de materiales delictivos. Imágenes que ilustran lo que Hito Steyerl ha definido como «imagen pobre»: «una miniatura, una idea errante en distribución gratuita, viajando a presión en lentas conexiones digitales, comprimida, reproducida, ripeada, remezclada, copiada y pegada en otros canales de distribución» (Steyerl, 2018: 33). Sin embargo, desde la perspectiva de la cultura visual contemporánea, algunas de estas imágenes tienen una correspondencia formal con motivos reconocibles (André, 2007) que se inscriben en una determinada tradición iconográfica. Uno de dichos motivos recurrentes, a través de los cuales el poder policial proyecta su imagen en la esfera pública, es el bodegón policial.

La citada denominación viene de sobra justificada por la evidente continuidad formal entre este tipo de construcción visual sintética, que resume en un solo espacio expositivo todo tipo de materiales incriminatorios incautados por las fuerzas de orden público (alijos de drogas y estupefacientes, arsenales de armas o materiales explosivos, pero también en ocasiones simples objetos personales) con aquellas obras históricas de género que, reproduciendo conjuntos de objetos de una misma familia tales como frutas o legumbres variadas, animales muertos, hierbas y flores, utensilios de cocina o de objetos de ajuar, entre otros, han recibido la denominación de naturalezas muertas (Sterling, 1959; Bryson, 2005) o de bodegones, en el caso español (Calvo, 1999; Cherry, 1999). Esta filiación directa entre esta forma de presentación de los objetos decomisados por una acción policial y su origen pictórico desde los tiempos del barroco es inmediata, tanto en la idea de reunir objetos inanimados, como también por el hecho de que estos objetos pertenecen a los hombres y mujeres que habitan ese espacio, aunque no estén presentes en la imagen.

La denominación «bodegón policial» se ha ido imponiendo como una manera de expresar esta forma de resumen sintético de un decomiso, un dispositivo puramente estético creado como un acto comunicativo que forma parte de la propia operación. La construcción del bodegón policial es un procedimiento que condensa iconográficamente esta acción, que los medios de comunicación transmiten sin cuestionar su naturaleza como creación estética, es decir sin detenerse a considerar los propios elementos que lo componen.

\section{La construcción del motivo}

¿Cómo enraíza el motivo del bodegón policial con la tradición iconográfica del bodegón pictórico? ¿Cuáles son las implicaciones a nivel interpretativo que la correspondencia visual revela sobre estas imágenes producidas por el poder policial? Nuestra hipótesis parte de establecer una comparación entre estos dos modelos de representación «en bodegón», y cómo esto explica la escenificación de estas imágenes policiales que buscan y consiguen su efecto comunicativo de crear culpabilidad. De entrada, el hecho de denominar a esta construcción policial de los decomisos «bodegón» es una manera de capturar su sentido político y estético: la policía enseña el resultado de sus acciones con una clara voluntad de influir estéticamente en los receptores de esta puesta en escena. $Y$ lo hacen a partir de recrear una forma contemporánea de una pintura de género histórica, también con una voluntad de construcción de identidad cultural, porque la resonancia implica directamente al carácter específico del bodegón español. Partiendo de estas cuestiones, el objetivo final del artículo es doble: por una parte, establecer los antecedentes que el motivo del bodegón policial actualiza; por otra, identificar el uso comunicativo que el poder hace de estas representaciones iconográficas en la contemporaneidad a través de su popularización en los medios.

El artículo parte del concepto de motivo y de los estudios interdisciplinares asociados a él (Didi-Huberman, 2007; Balló y Bergala, 2016; Walker, 2005), para referirnos a un modelo iconográfico de representación cultural que se transmite y se reinterpreta a través de la historia de las imágenes fomentando el reconocimiento narrativo y emocional. Las nociones de "pseudomorfosis» de Erwin Panofsky (1964: 26-27; 1972: 95) y de "Supervivencia» de Aby Warburg (Didi-Huberman, 2009) nos sirven para analizar la continua reapropiación de iconos, arquetipos e imágenes comunes de manera no necesariamente consciente sino en tanto que esquema cultural. Bajo nuestro punto de vista, el bodegón policial es un motivo ejemplar de un proceso de actualización y reapropiación de un género pictórico y de un dispositivo formal propio del barroco hispánico.

Respecto al uso comunicativo que el poder hace de algunos de estos modelos de representación, nos enmarcamos en los estudios de iconografía política -realizados por Carlo Ginzburg (2013), Horst Bredekamp (2007) o in- 
vestigaciones como la Handbuch der politischen Ikonographie (2011)- inspirados en el pensamiento de Aby Warburg, quien se propuso hacer de las imágenes en sí mismas el eje de un ambicioso proyecto intelectual situado bajo el signo de esa memoria iconográfica universal; proyecto cuya culminación justamente habría de consistir en un intrincado catálogo de los principales motivos que encontramos repetidos -con ligeras variantes- a lo largo de nuestra historia, e incluso en otras culturas no occidentales: el llamado Atlas Mnemosyne (Didi-Huberman, 2009).

En el caso de estudio que nos atañe, nos centraremos en las imágenes de bodegones policiales publicadas en la prensa española y, ocasionalmente, en las aparecidas tanto en prensa digital como en la televisión y las redes sociales. Cabe añadir que la extensión de la investigación en materia iconográfica más allá de los dominios tradicionales de la Historia del Arte y de las imágenes consideradas artísticas en direcciones como la fotografía de prensa (u otros medios), formaba parte ya de las intenciones iniciales del proyecto de Warburg, aunque solo pudiera iniciarlo en los últimos años de su vida (Wind y Gombrich, 2019). Así, toda la inmensa variedad de imágenes que se nos ofrecen en los medios al margen de los estrictos límites de las bellas artes, desde la publicidad hasta la vasta familia de toda clase de reportajes visuales, se nos aparecen como catálogo de nuevos motivos no contemplados inicialmente o nuevas categorías de imágenes que el curso del tiempo ha ido desplegando.

\section{La identidad hispánica del motivo}

Como hemos apuntado al inicio, la riqueza formal en las composiciones en bodegón de los cuerpos de policía españoles -analizadas a lo largo de la investigación- apuntan a la especificidad del motivo dentro de la cultura visual hispánica. Una prueba de ello nos la da la publicación del número especial de la revista visual 4 Taxis titulado Evidence: natures mortes de la police, police still lives, bodegones policiales (Aphesbero y Colomine, 2003) en la cual se reúnen alrededor de 600 imágenes relativas a los diversos decomisos de las policías del mundo, documentados fotográficamente. De manera significativa la única de estas imágenes que responde a los parámetros compositivos del bodegón es la primera de ellas, tomada en Sevilla en 1990 por parte de la Policía Nacional y que la revista reconoce que inspiró la propuesta. El resto de las fotografías son simples imágenes de decomisos por parte de las policías de Estados Unidos, México o China, entre otros países, sin esa capacidad de transmisión estética que significa la puesta de los objetos en bodegón de los diversos cuerpos policiales españoles como la Guardia Civil, la Policía Nacional, los Mossos d'Esquadra o la Ertzaintza.

El origen del bodegón pictórico como género se remonta a finales del siglo XVI, y tiene una especial relevancia durante la monarquía hispánica, ligado a un cruce entre el espíritu de la Contrarreforma y del gusto manierista y barroco (Pérez, 1983; Jordan, 1985). El género pictórico, que conoce su máximo esplendor con pintores como Zurbarán, Valdés Leal o Sánchez Cotán, entre otros muchos, se caracteriza por la acumulación sobre una mesa de elementos vegetales, animales y minerales, cuya selección y tratamiento pictórico (iluminación, gama cromática, etc.) destacan por su sobriedad y la reverberación moral que transmiten al espectador. En el histórico tratado de pintura de Francisco Pacheco, Arte de la pintura, escrito en 1641, el autor utiliza el término «bodegones», para describir las pinturas resultantes de acumular lo que él llama «pinturas de flores y frutas» (1990: 503) con las «pinturas de animales y aves, pescaderías y bodegones» (516). El autor relata la voluntad de combinar figuras orgánicas e inorgánicas: "estudio de toda suerte de animales, aves y peces, de las calderas de cobre y diferentes vasos» (517). El texto de Pacheco confirma que el concepto «bodegón» es una denominación española, que se adoptó cuando el género pictórico era emergente y aún no estaba consolidado, en contraste con los términos Stilleven, Still life o Nature morte que se utilizaban en los otros países donde el género se cultivó.

Muy pronto este «bodegón español» marcaría algunas de sus características formales. Los cuadros de Juan Sánchez Cotán, por ejemplo, ya plantean esta composición en perspectiva, con una idea de fondo presente, oscuro y tangible. Esta densidad en la profundidad marca la característica suspensión temporal de sus cuadros, como Bodegón de caza, hortalizas y frutas (1602), donde los elementos que los componen están en un proceso orgánico evolutivo de descomposición, pero a la vez son también intemporales, como si la iconografía del bodegón planteara, en su inmovilidad, una traza de eternidad. 
En su evolución, el bodegón plantea unos recursos comunes de gran influencia: el despliegue de los objetos heterogéneos en una mesa, las geometrías que presiden la composición, y un orden estético que propone nuevas formas de expresividad a partir del silencio visual. Heterogeneidad de objetos como los que se sitúan en Bodegón con conchas y un reloj (1652) de Antonio de Pereda, donde sobre una mesa con manto se disponen objetos como platos y jarrones de cerámica, con una serie de caracolas, avellanas y nueces abiertas, que combinan lo que el tiempo transforma y lo que resiste a su paso.

Pero sabemos que el bodegón y las naturalezas muertas también proponen, en algunas obras, un mensaje alegórico tal y como plantea Norbert Schneider (2003). En estos casos se pone de relieve que en la disposición significativa de los objetos se transmite la idea del transcurso del tiempo y del carácter efímero de la vida, un aspecto admonitorio que es propio del género: la muerte es igual para todos. En este sentido, el bodegón es una fuente permanente de alegorías, que aluden a la condición humana, como en la representación de la avaricia o la vanidad (Berger, 2016: 93). En el cuadro de Juan Valdés Leal, Alegoría de la vanidad (1660), esta se asocia a una mesa repleta de objetos como monedas, joyas, una corona o una tiara, que se combinan con otros objetos que avisan del carácter fugaz de la existencia, como unas flores marchitas, un reloj de arena, una calavera o una vela apagada. Muchos de estos elementos ya aparecían en otro bodegón alegórico de Antonio de Pereda ${ }^{1}$, El sueño del caballero (1650), que insiste en la intención de advertencia y que también pone sobre la mesa todos aquellos elementos que pueden simbolizar la misma idea del tiempo fugaz, como de nuevo la calavera, la vela apagada o el reloj, junto a dinero, joyas, una máscara teatral, que representa la hipocresía, y un arma de fuego.

Existe otro nexo sobre la relación entre las fotografías actuales de los decomisos realizados por los cuerpos de seguridad del Estado y la tradición hispánica del bodegón, que tiene que ver con el momento histórico de su reaparición. Se puede establecer una analogía entre ciertas particularidades de la época barroca y determinadas tendencias contemporáneas (Benjamin, 1990) que han llevado a algunos pensadores a referirse a una era neobarroca (Calabrese, 1999; Sarduy, 1975), que se basa también en el sentido de la alegoría, la heterogeneidad, la repetición y la conciencia de puesta en escena. En el caso de la monarquía hispánica, esta analogía se funda en el régimen de visualidad que será propio de la modernidad (De la Flor, 2009: 9). La imagen se convierte así ya no meramente en un doble del mundo sino en un mundo en sí misma, o en el mundo, introduciendo un principio de racionalidad y de orden (Le Breton, 2003: 204). Así, pues, resultará característica del mundo hispánico durante el Barroco una voluntad de atención y vigilancia orientadas a un conocimiento exhaustivo, como una característica del ejercicio del poder y su fuerza punitiva (De la Flor, 2009: 109-116). El bodegón policial en España, como instrumento comunicativo del Estado moderno, asume estas funciones de vigilancia y control llevadas al paroxismo con la ayuda de técnicas de producción mecánica de la imagen.

Por todo ello, cuando los investigadores policiales dedican los pocos minutos de que disponen para preparar el bodegón para ser fotografiado y distribuido a los medios de comunicación reproducen, de manera consciente o no, algunos elementos iconográficos del bodegón, con los mismos tintes alegóricos de muchas de las obras originales. Como afirma de manera elocuente Susan Sontag, «aun cuando a los fotógrafos les interese sobre todo reflejar la realidad, siguen acechados por los clásicos imperativos del gusto y la conciencia» (2008: 16).

\section{El bodegón policial, el orden del poder}

En paralelo a la pervivencia de la tradición pictórica del género, el bodegón policial enraíza también con una serie de figuraciones e imágenes del orden que constituyen sendas expresiones del poder. Tal y como ha demostrado de manera elocuente Foucault (1980), en el horizonte cronológico de la modernidad, el poder, entendido en un sentido cada vez más abstracto como administración del dominio, experimenta un proceso creciente de capilarización que lo lleva a ejercerse a través de su control sobre las más diversas instancias: el espacio, los cuerpos, la educación y también la circulación del saber (Deleuze, 1990). La racionalidad moderna no es, pues, inocente, sino la consumada expresión de un poder que se adhiere hasta disciplinar los más remotos ámbitos. De ahí que el saber que se constituye en la expresión o la manifestación genuina del poder adopte la 
forma de la racionalidad: omnímoda (todo lo alcanza), omnipotente (todo lo somete), omnisciente (todo lo conoce). El poder reúne, ordena y controla; es, pues, inventario, catálogo y, finalmente, panóptico.

El binomio bodegón policial-expresión del poder pone de relieve que no solo el precedente pictórico explica algunos de los usos contemporáneos del motivo. Alejadas de lo artístico, las representaciones de la ilustración científica y técnica abren otras vías de reflexión. En primer lugar, encontramos entre tales imágenes las que documentan y dan razón de los numerosos gabinetes de curiosidades, existentes en Europa durante los siglos XV y XVI (Von Schlosser, 1988). Estos espacios -caóticas acumulaciones de objetos variopintos- pertenecían durante el Renacimiento y el Barroco ya sea a príncipes, bien a cortesanos eminentes o a sabios eruditos y coleccionistas, estando vinculados a imperios o reinos y, en ocasiones, a asociaciones filantrópicas o científicas como la célebre Academia dei Lincei italiana. Su designio era el de ejemplificar a través de la variedad de muestras el alcance del saber, en unos casos por el saber mismo y en otros como extensión o manifestación del poder del soberano.

En los gabinetes de curiosidades no hay distinción entre naturaleza y arte. Reúnen objetos antiguos y fetiches exóticos, así como prodigios naturales procedentes de las antípodas o de eras geológicas lejanas. En su conjunto, las colecciones están ordenadas conforme a analogías, a veces según formas y a veces según colores. En cualquier caso, el todo de la colección, que representa la réplica del mundo a escala reducida, aparece a los ojos del visitante como penetrado por un orden inteligible. Frente al azar que parece reinar en un mundo natural lleno de anomalías, aberraciones o simples casualidades, la colección -su reproducción en miniatura- se caracteriza por ser expresión de la racionalidad. Y si así resulta de la sucesión de anaqueles, armarios, estanterías o cajones en los que se va desplegando, así debe ser también en las imágenes que la representan o en los catálogos y resúmenes que la ilustran.

De ahí que los conjuntos bien organizados de objetos que aparecen en las láminas que ilustran las colecciones de las cámaras de maravillas constituyan un antecedente afín y otra más que verosímil fuente de inspiración para los actuales bodegones policiales. Pues, en efecto, estos últimos, tal y como ya hemos apuntado, presentan los objetos que los integran cuidadosamente distribuidos por toda la superficie que los acoge, con frecuencia alineados con un celo y una destreza dignos de geómetras o agrimensores, y generalmente ordenados por su naturaleza: sobres o bolsas de plástico conteniendo la droga incautada unos junto a otros formando hileras, documentos de identidad, pasaportes o visados, billetes falsos, monedas apiladas, armas formando estructuras geométricas...

Pero además de láminas (y muebles: vitrinas, expositores, cajas...) existen también otras instancias y dispositivos gráficos que pueden ser considerados antecedentes y términos de comparación muy significativos en relación a los bodegones policiales contemporáneos; instancias y dispositivos gráficos donde se pone de manifiesto como auténtico poder la labor ordenadora (que es a la vez voluntad de disciplinar) de la razón. Sin pretender ser exhaustivos, se pueden citar aquí, entre otros: árboles del conocimiento, tablas o esquemas clasificatorios para las diversas disciplinas científicas (desde árboles genealógicos hasta tablas comparativas de fisiognomía o clasificatorias al estilo de Lamarck) o diagramas que ilustran la evolución de un aspecto cualquiera de la morfología humana, animal o vegetal. Desde la llustración hasta nuestros días, el poder ha expresado a través de la racionalidad tanto su alcance universal (a través de la reserva, la colección o el inventario, entre otras figuras) como su poder disciplinario (a través de índices, catálogos razonados o clasificaciones).

Por su parte, investigaciones como la de John Tagg han probado el concurso de la fotografía en dicho proceso de construcción y de afianzamiento del moderno aparato del Estado (1988: 63). La cronología de la generalización y desarrollo técnico en el uso de la fotografía coincide con los hitos más importantes en la consolidación y perfeccionamiento de la maquinaria del Estado moderno, como la creación de fuerzas de orden público en sustitución de los antiguos cuerpos de vigilancia gremiales. A partir del momento en que la vigilancia se destaca como una de las principales funciones del aparato estatal, la fotografía se introduce cada vez más en las prácticas habituales de la policía (Tagg: 71-72). En síntesis, la fotografía sistematiza el catálogo de imágenes, primero de reclusos, más tarde, de supuestos enfermos psiquiátricos e incluso de escolares (Tagg: 62), hasta llegar a la documentación de las evidencias incriminatorias, como serán los bodegones policiales. 


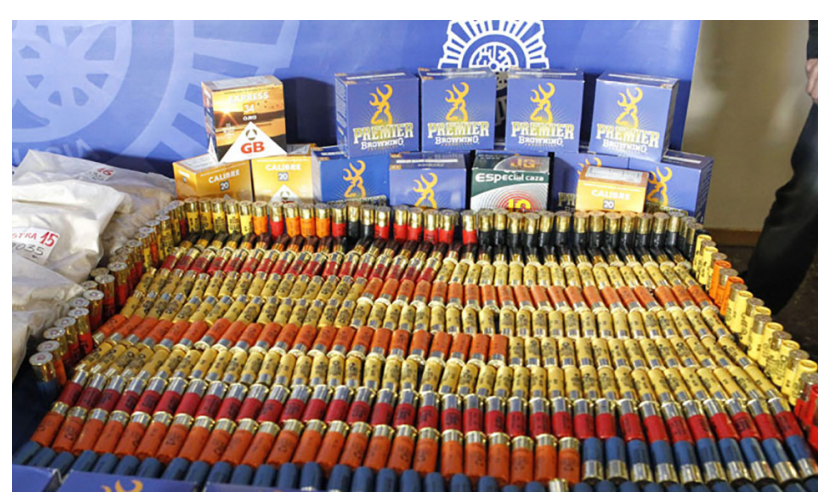

1. Decomiso de 45 kilos de heroína, Madrid, 2013

\section{Las pervivencias formales del bodegón policial}

Heterogeneidad entre orgánico e inorgánico, soporte unitario, perspectiva, geometrías estrictas, señalización gráfica, sentido del color -policromo o monocromo-, disposición volumétrica, repetición, sentido del cierre visual y, especialmente, orden. Todos estos elementos que hemos podido identificar en los antecedentes del motivo, se deben tener en cuenta a la hora de analizar los bodegones policiales aparecidos en los medios españoles. En la mayoría de las imágenes encontramos cómo la presentación de los materiales decomisados sigue al pie de la letra dos de las características fundamentales del bodegón barroco: por un lado, los principios compositivos de horizontalidad, combinada con la introducción de objetos en disposición diagonal, que refuerza la idea de perspectiva; y por el otro la presencia de objetos que están en evolución biológica junto con otros de

2. «Operación Vulpes» Ilevada a cabo en 14 provincias españolas, 2016

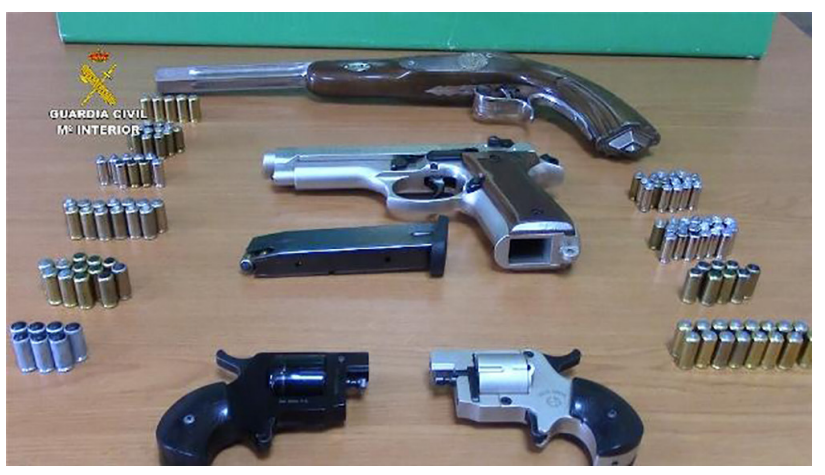

mineralizados, articulando así el discurso del tiempo y su discurrir, inherente al género fundacional.

Respecto a las cuestiones compositivas, los bodegones policiales con decomisos de un mismo objeto o material (armas, pasaportes, alijos de droga, etc.) son muy ilustrativas. Tomemos como ejemplo el decomiso de heroína que realizó la Policía Nacional en Madrid en marzo de 2013², uno de los más relevantes de los últimos años según los medios-. El bodegón resultante [1] lo componen principalmente los cilindros de colores en los que se transportaba la heroína -aunque no hay ninguna indicación sobre ello-, escrupulosamente alineados unos al lado de los otros en hileras perfectamente definidas y ordenados por gamas cromáticas -del azul al rojo, del amarillo al naranja y cerrando la composición el negro-, generando así en el conjunto un efecto de serialidad y multiplicación que refuerza tanto el sentido estético de la composición como la transmisión de la idea de «cantidad ingente» de droga decomisada.

Esta búsqueda de la composición en perspectiva a partir de la creación de geometrías se observa muy bien en los decomisos de armas. En el año 2016, en el marco de la conocida como «Operación Vulpes»³, la Guardia Civil decidió realizar un bodegón policial muy conceptual, a pesar de la envergadura del decomiso -500 armas y 8.000 cartuchos de munición- a partir de cuatro pistolas -y un cargador- de medidas y marcas diferentes, rodeados de distintos grupos de balas, buscando de nuevo el efecto de la perspectiva y el equilibrio geométrico [2].

El gusto estético en la colocación del armamento entronca con la tradición clásica de una obra como Bodegón de objetos de orfebrería (1624) de Juan Bautista de Espinosa [3], donde sobre una mesa con un manto blanco con pliegues se disponen platos de plata en vertical, dos botellas de cristal, ollas de cerámica, saleros, dos cuchillos en diagonal, y una naranja abierta, en una composición que destaca por su geometría y su carácter monocromo y que también anticipa la combinación objetual de lo orgánico y lo inorgánico, característica del bodegón policial.

Esta conjunción de elementos diferentes se hace sentir en un bodegón policial donde la presencia de dos papayas abiertas y otras situadas en cajas se combina con la droga que se alinea al lado [4]. Se trata de una confiscación de la Policía Nacional del año 2014: 32 kilos de cocaína que habían Ilegado a España desde la República Dominicana, 
ocultas en 120 cajas de papayas ${ }^{4}$. Una obra bastante pura: frutas abiertas en canal mostrando sus semillas -o sea, la vida y la muerte- junto a la droga que viajaba en ellas, evocando exotismo, ingenio y aventura.

Más compleja es la forma de presentación de un bodegón policial donde también se combinan elementos orgánicos con inorgánicos. En la desarticulación de un grupo dedicado al tráfico de droga en Aragón, bajo el nombre de «Operación Herculano» ${ }^{5}$, en agosto de 2011, la Policía Nacional produjo un bodegón fruto de cinco registros en Zaragoza y en los pueblos de Épila y Cuarte de Herva. Si en el bodegón anterior destacaban las frutas, este bodegón entronca con la «pintura de hierbas», mencionada por Felipe de Guevara en su manuscrito escrito hacia 1560, Comentarios de la pintura ${ }^{6}$. La droga está representada en los paquetes identificados como tales, pero también en las macetas, en una combinación que quiere poner énfasis en el proceso de fabricación, en el antes y el después.

Más allá de estas características, el corpus de imágenes analizado para la investigación dibuja una tendencia formal hacia el minimalismo. Encontramos numerosos ejemplos de bodegones policiales que rehúyen el objeto en favor del concepto, convirtiendo el mínimo de pruebas acumuladas en un signo de estilo. Este es el caso, por ejemplo, del bodegón policial que representa un decomiso de droga realizado por la Guardia Civil en Vinarós en 2013²: cua-

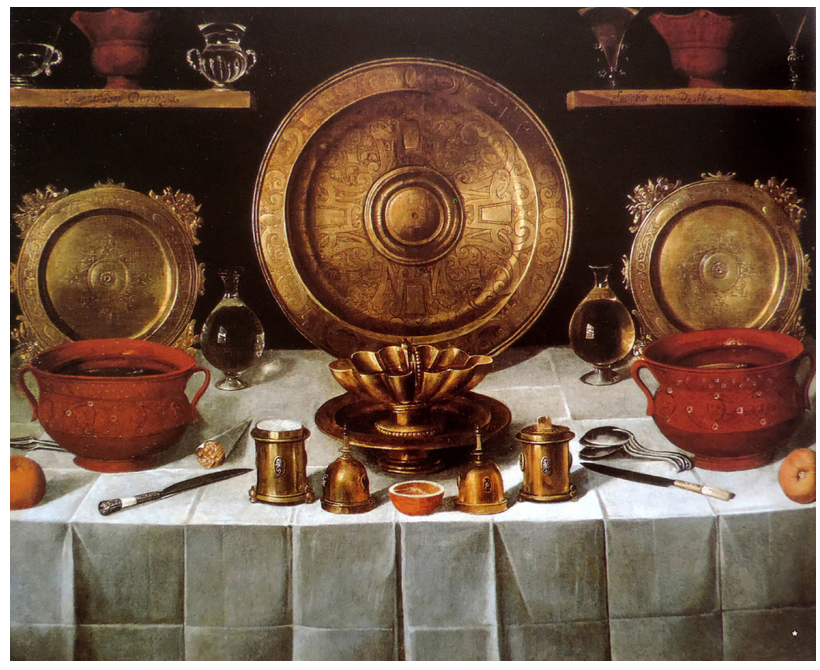

3. Bodegón con objetos de orfebrería, Juan Bautista de Espinosa, 1624

tro papelinas de cocaína -tres pequeñas y una más grande abierta- puestas encima de una balanza que indica 12 gramos; el peso, el tipo de sustancia y el símbolo del cuerpo policial que ha realizado la acción reunidos en una sola imagen.

En la misma línea minimalista, la Policía Local de Coslada (Madrid) realiza una composición visual con nueve billetes -que suman $125 €$-, ocho piedras pequeñas de hachís, un porro a medio fumar puesto en una bolsita de plástico y carteles de la Unidad Canina de la Policía Local que identifican
4. Decomiso de 32 kilos de cocaína ocultos en papayas, Madrid, 2015

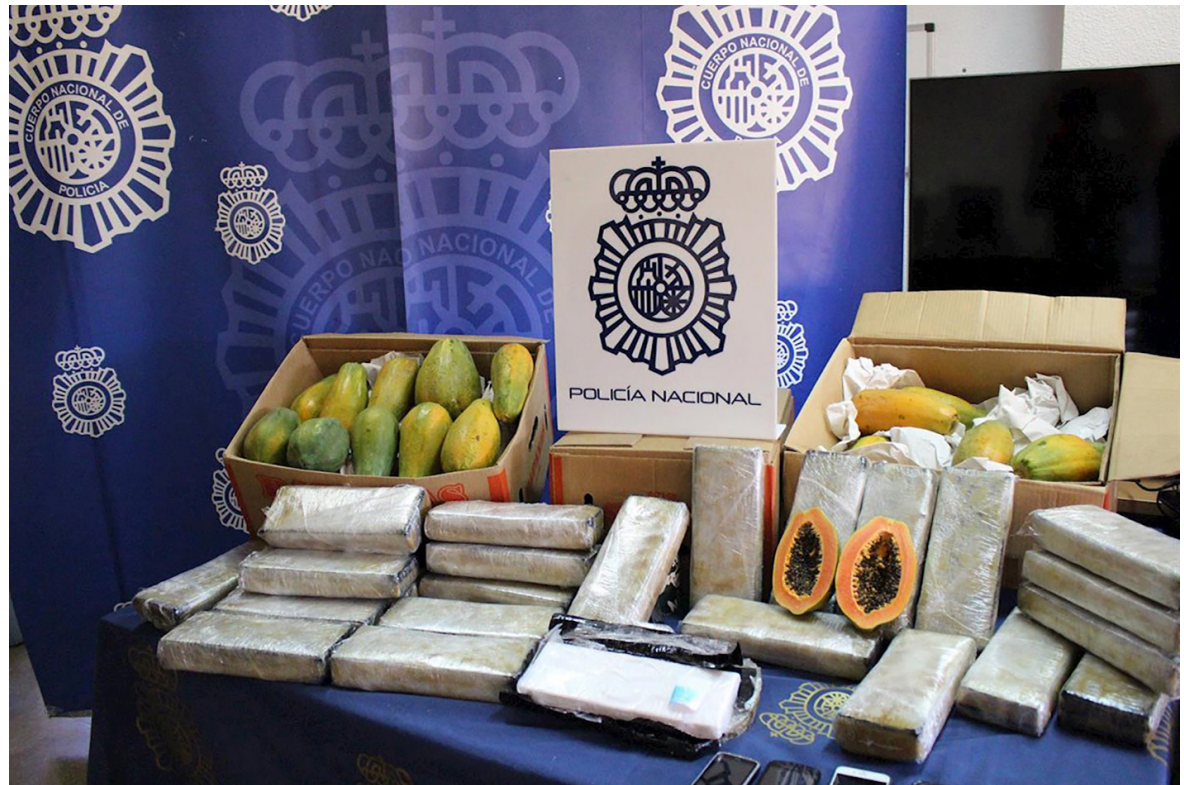




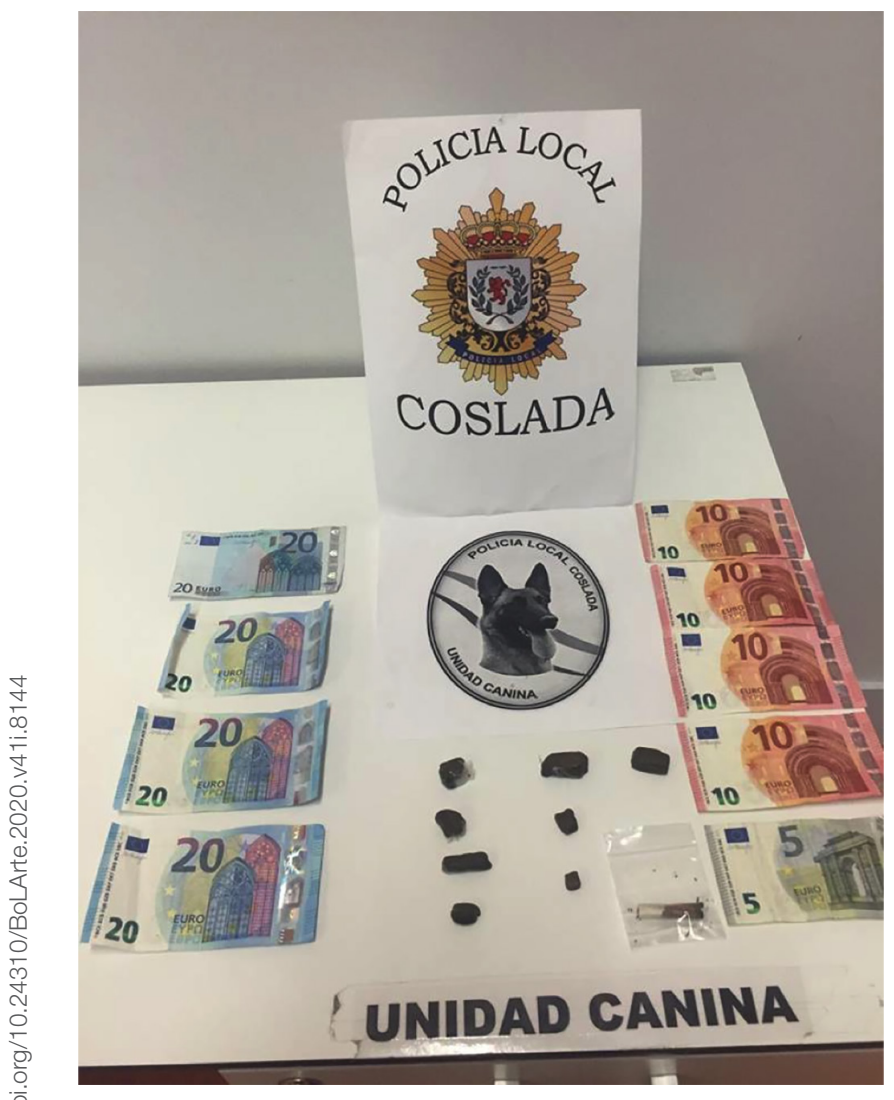

5. Decomiso realizado por la Sección canina de la Policía Local de Coslada, 2017

la autoría y mérito del decomiso ${ }^{8}$ [5]. Ambos bodegones policiales participan del gusto minimalista dentro del género al mismo tiempo que muestran -intencionadamente o no- un fuerte carácter irónico. En el caso español, el mismo Sánchez Cotán tiene versiones sintéticas de algunos bodegones suyos anteriores, como Bodegón con cardo y francolí (hacia 1602) o Bodegón con cardo y zanahorias (1602), jugando con la ambivalencia de lo que está presente y lo ausente. En Bodegón con frutos secos, de Francisco de Burgos Mantilla (1631), detectamos este mismo principio minimalista: una obra en disposición monocroma y severa, que muestra en primer plano tres papelinas de donde emergen las nueces, pasas y otros frutos secos, sin un orden aparente, pero marcado por el rigor minimalista de la composición.

Sin embargo, es en los bodegones del cubismo y el surrealismo donde se observa una mayor capacidad de abstracción y de ironía. Se trata de una tendencia donde la presencia de botellas, recortes de periódico, monedas o cuchillos omnipresentes hacen patente la tensión de la construcción visual, con elementos heterogéneos que pueden parecer ingenuos confrontados con otros que plantean una violencia en tensión. Así lo ilustran las obras de Juan Gris entre otros cubistas- como Botellas y cuchillo (1912) [6] o Naturaleza muerta delante del armario (1920), donde un cuchillo, acompañado de frutas y botellas, se hace presente en primer término en ambas composiciones.

Este equivalente formal lo encontramos en algunos de los bodegones policiales analizados, como en el caso de 2017 en la localidad de Molina de Segura (Murcia) donde un padre tuvo retenidos a sus tres hijos en su domicilio amenazando su integridad con distintos utensilios ${ }^{9}$. El bodegón resultante [7] de esta operación llevada a cabo por la Policía Nacional es un cuchillo de sierra de grandes dimensiones junto a unas llaves de un coche al lado. Los dos objetos por sí solos son incapaces de traducir lo acontecido, el significado surge de la relación o asociación entre ambos, como si se tratara de un eco compositivo de inspiración surrealista del rayograma de Man Ray Gun and Key $n .^{\circ} 37(1922)^{10}$. Esto significa que un bodegón policial con detalles mínimos no equivale a constatar que no hay nada más a enseñar en función de lo incautado, sino que es una forma de crear un sentido diferente entre los objetos presentados. En este caso, la culpabilidad ya no la proporciona tanto la acumulación, la heterogeneidad y la repetición, que son los principios básicos del bodegón policial tradicional, sino la capacidad de los objetos de establecer un diálogo visual entre ellos, como un relato icónico desplegado sobre la mesa. La conjunción de objetos solo adquiere sentido en la unión conceptual que puede hacer el espectador ante la imagen que los vincula.

Tal y como hemos visto en los ejemplos iniciales, sabemos también que el minimalismo no se basa únicamente en la escasez de objetos representados, sino en la multiplicación de un mismo objeto, una repetición que es uno de los mecanismos habituales de la culpabilización -de la que hablaremos a continuación- generada en la construcción del bodegón policial. Esta idea de un mismo objeto repetitivo se hace sentir cuando el objeto es anodino, como la confiscación de botellas, un elemento objetual que es afín al género a lo largo de toda su trayectoria histórica, especialmente en su representación moderna. Aunque solo sea por esta filiación 
pictórica, los bodegones contemporáneos de botellas suelen ser una imagen recurrente en los decomisos policiales, como una manera de mantener un vínculo significativo con la tradición y el origen etimológico del término en España.

\section{El bodegón policial: la creación de culpabilidad}

El carácter alegórico de admonición y la racionalidad y orden formales que hemos detallado en los apartados anteriores hacen del bodegón policial una imagen creadora de culpabilidad en su simple recreación. Por ello, en la mayor parte del corpus de imágenes analizadas en la prensa, identificamos la voluntad por parte de los cuerpos policiales de realizar una creación compositiva, principal indicador para ser considerado bodegón como tal. Como hemos demostrado en las páginas anteriores, no basta con unos objetos dejados sobre una mesa para que un bodegón policial se convierta en representativo y, en consecuencia, en índice de un delito. Los objetos, por encima de las personas (criminales o no), son los constructores de un determinado relato (Baudrillard, 1969). Su agrupación bajo un criterio formal -aunque cada uno de ellos por separado pudiera tener otro significadoaumenta la percepción de culpabilidad; hasta el punto de que el motivo está asociado en la cultura popular a la figuración de la delincuencia (Lombroso, 2006).

Este hecho es observable a través de distintos ejemplos concretos de la muestra analizada. Uno de ellos fue el caso de la detención de Fernando Blanco y Margarita Garau, más conocidos como «los padres de Nadia», acusados

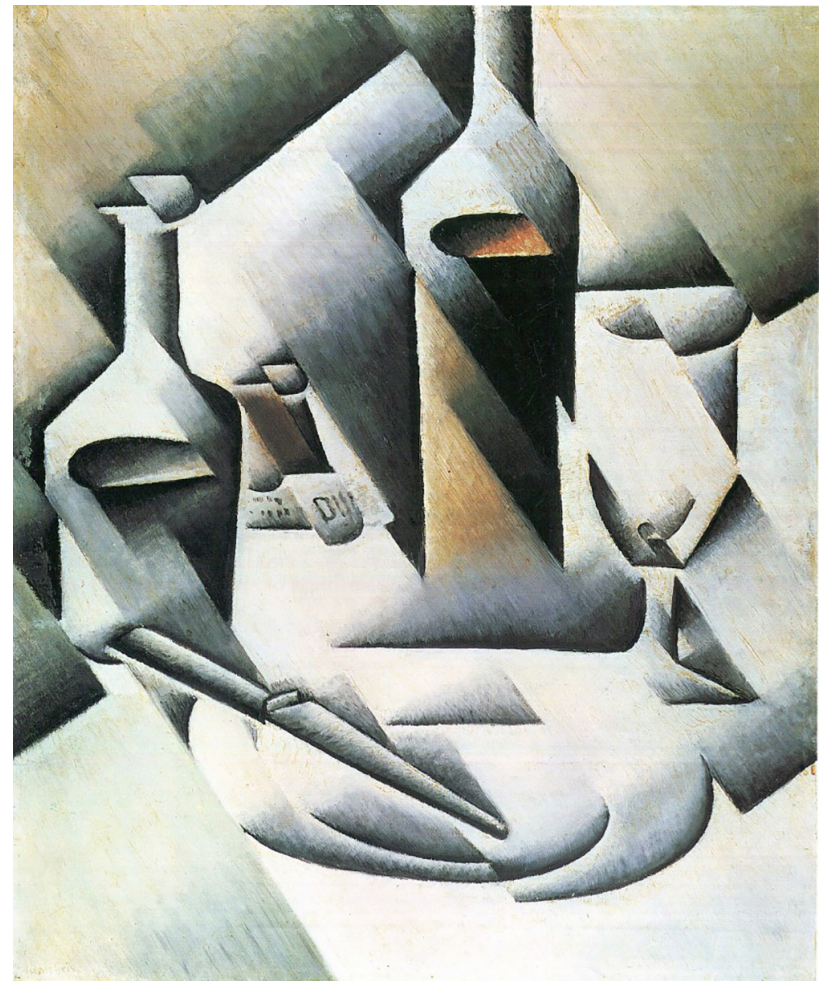

6. Botellas y cuchillo, Juan Gris, 1912

de estafa a partir de conocerse que habían mentido sobre el destino del dinero recogido en aportaciones populares para pagar el tratamiento médico de la enfermedad de su hija ${ }^{11}$. El bodegón que se puso en escena después de la inspección de la casa familiar, en marzo de 2017, es un ejemplo paradigmático de la intención de crear culpabilidad [8]. ¿Qué

7. Cuchillo y llaves del vehículo, Molina de Segura (Murcia), 2017

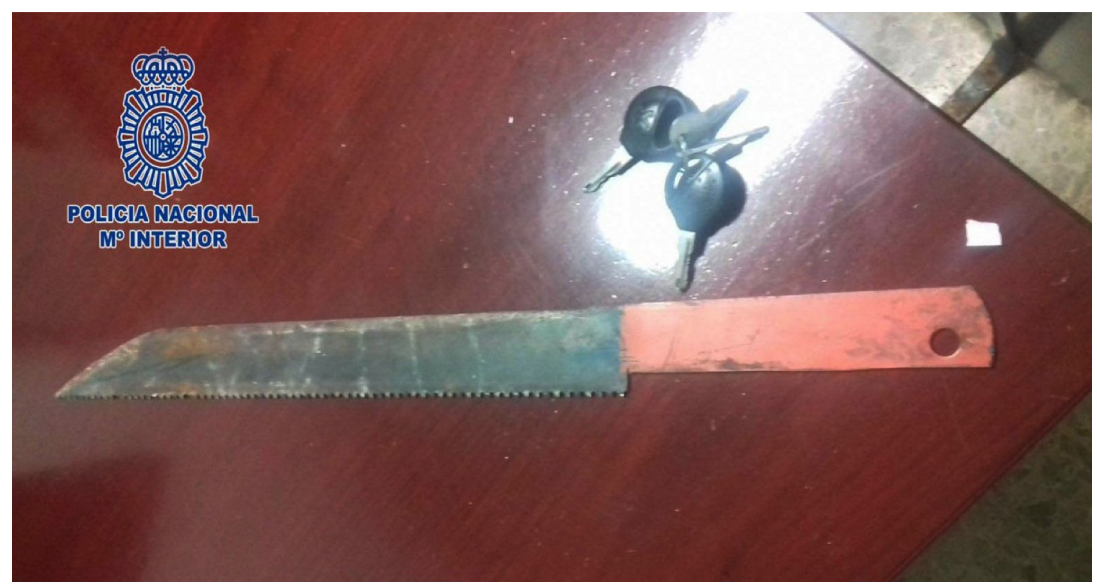




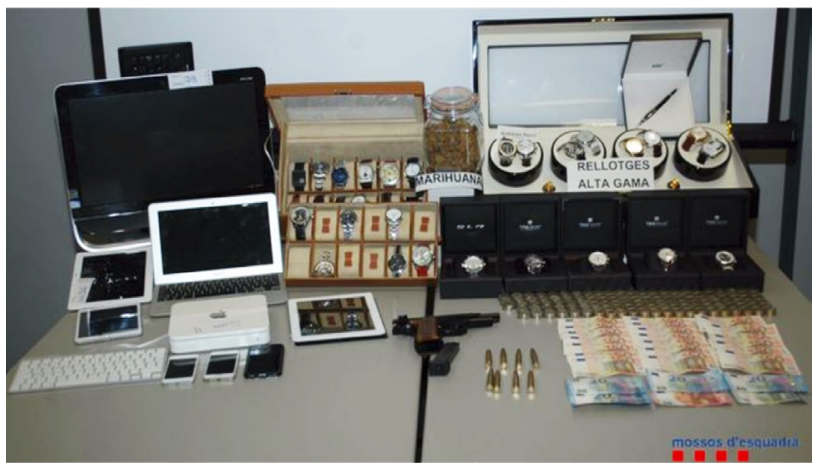

8. Material incautado en el domicilio familiar de «los padres de Nadia», La Seu d'Urgell (Lérida), 2017

vemos en este bodegón? En la parte izquierda: un ordenador de mesa, un portátil, un disco duro, dos tabletas y tres móviles. En la parte central domina una pistola de fogueo (encontrada en el coche del padre) y las balas correspondientes, dispuestas como si la pareja fuera afín a la violencia. Después, encontramos un despliegue de relojes separados entre los que están agrupados bajo el rótulo «alta gama» y los que no. Un conjunto de monedas apiladas, un conjunto de billetes, una pluma estilográfica y un bote de hierbas que se especifica que es «marihuana» acaban de componer el bodegón. La impresión producida por la agrupación de todos estos materiales «en bodegón» es que los padres de
Nadia dedicaron todo el dinero que recaudaron a llevar una vida de lujo y malgastar los recursos de los demás. Pero de todos los objetos expuestos, solo los ocho relojes que el constructor del bodegón ha etiquetado como "alta gama", podrían responder a este principio. En todo caso, el creador del dispositivo refuerza el efecto de culpabilización con un texto anunciador. Todo lo demás es la suma de elementos heterogéneos que por sí solos no responden a la categoría de objetos de lujo pero que puestos juntos pueden aspirar a crear esta intención.

Otro caso de esta inducción a la culpabilidad a partir de la composición formal «en bodegón», es el de la acción de los Mossos d'Esquadra en 2012, en una casa del barrio del Raval, en Barcelona, donde vivían catorce jóvenes que habían sido desalojados de la vivienda que ocupaban y compartían con el objetivo de crear un centro social ${ }^{12}$. De los objetos presentados en bodegón [9] destacaban varios cascos de motorista, varias rodilleras, llaves de pared, un chaleco antirreflejante, una cadena, tres palos metálicos y un martillo, situado en el centro. Al fondo de la escena, bordeando el emblema de los Mossos, se habían colgado dos posters, uno del movimiento animalista y el otro reclamando libertad de expresión. ¿Qué nos dice esta composición? Todos los objetos son cotidianos, sin ser demostrativos de ningún tipo de violencia. Sin embargo, puestos en escena por la policía, a partir de este formato de inventario repeti-

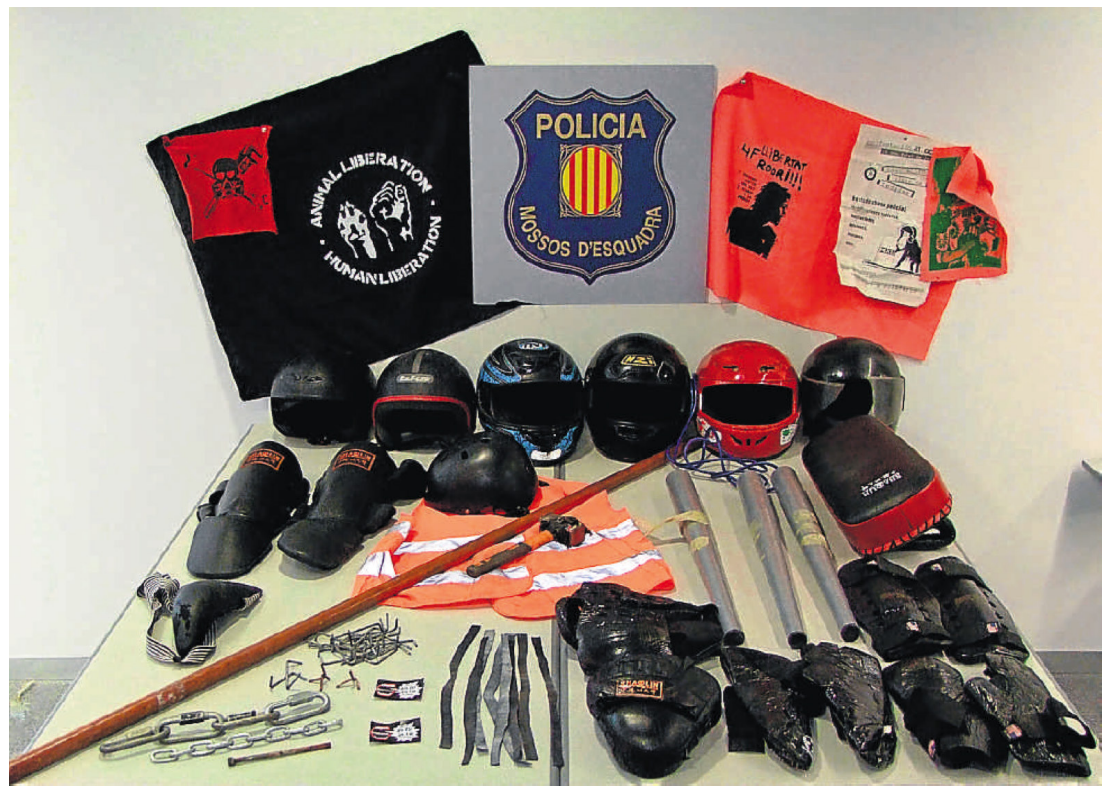

9. Material decomisado durante el desalojo de 14 jóvenes de una casa en el barrio del Raval, Barcelona, 2012 
tivo, se genera una sospecha. A falta de cualquier arma de fuego, navaja o instrumento similar, la composición daba una importancia especial al martillo, como si su sola presencia abriera la posibilidad de una acción violenta concertada. La versión oficial del decomiso en la página web de los Mossos informaba que el 9 de mayo del 2012 se desalojó un edificio ocupado del barrio del Raval donde vivían catorce personas. Se especificaba que hubo una detención, que los otros fueron imputados y que se encontró «material susceptible de ser utilizado en la violencia urbana». El discurso del poder policial se sustenta a nivel visual a partir del inventario y ordenación de los objetos decomisados.

\section{Conclusiones}

El control del relato visual por parte del poder no es un fenómeno nuevo (Burke, 2005) y en la tarea del creador de los bodegones policiales podemos encontrar reminiscencias de los pintores de batallas y los fotógrafos y cineastas de gue- rra, encargados por sus respectivos ejércitos de crear tendencia ideológica basada en la exaltación de lo propio y la denuncia de la debilidad o crueldad del adversario (Monegal, Ridao y Torres, 2004: 22-25). En este sentido, consideramos que el motivo del bodegón policial contiene toda la complejidad de la esfera pública: es claramente una imagen organizada desde el poder, policial en este caso, que se construye de forma consciente y precisa y que, por su simple composición visual, produce un impacto difícilmente reversible. Solo por el hecho de estar dispuestos en forma de bodegón, toda una serie de objetos adquieren categoría de signos inequívocos de culpabilidad. El bodegón policial es un claro ejemplo de cómo un género pictórico es reinterpretado y deviene motivo visual, con todas sus características: que evoluciona en sus herramientas expresivas, que integra todos los lenguajes de cara a construir una imagen única que apela a la memoria iconográfica y que tiene una evidente voluntad comunicativa. Es un caso evidente de imagen superviviente, utilizada de manera interesada, y que tiende cada vez más a evidenciar las raíces de su impregnación.

\section{Notas}

1 Según Enrique Valdivieso, el autor de El sueño del caballero sería Francisco Palacios. Ver: VALDIVIESO, Enrique (2002), Vanidades y desengaños en la pintura española del siglo de oro, Fundación de Apoyo a la Historia de Arte Hispánico, Madrid.

2 «Detenido en Madrid uno de los principales distribuidores de heroína a gran escala en España». En: <https://www.rtve.es/noticias/20130315/detenido-madrid-uno-principales-distribuidores-heroina-gran-escala/617621.shtml> (fecha de consulta: 23-06-2020).

3 «La Guardia Civil desarticula una organización criminal dedicada a la adquisición y venta de armas de fuego». En: <http://www.interior.gob.es/ca/prensa/ noticias/-/asset_publisher/GHU8Ap6ztgsg/content/id/6067218> (fecha de consulta: 23-06-2020).

4 «Incautados 32 kilos de cocaína ocultos en un cargamento de papayas». En: <https://www.lavanguardia.com/sucesos/20150520/54431348974/cocaina-oculta-cargamento-papayas.html> (fecha de consulta: 23-06-2020).

5 PÉREZ, Ramón, «Desarticulada en Zaragoza una banda que "importaba" y distribuía droga». En: <https://www.abc.es/espana/aragon/abci-droga-zaragoza-201108020000_noticia.html> (fecha de consulta: 23-06-2020)

6 En el capítulo dedicado a la «Pintura de las Yerbas», Guevara avisa al principio que «no hay nada nuevo debajo del sol» y sitúa su germen en la época de los artistas de la corte de Nerón: «Este es el origen que la Pintura de las yerbas acerca de los Romanos tuvo, la cual en nuestros tiempos al pie de la letra han imitado los Modernos" (Guevara, 1788: 115-117).

7 «Incautan 12 gramos de cocaína a un trabajador de ocio de Vinaròs». En: <https://www.eldiari.online/incautan-12-gramos-de-cocaina-a-un-trabajador-delocio-de-vinaros/> (fecha de consulta: 23-06-2020).

8 «Risas en las redes sociales con una redada antidroga de la Policía de Coslada». En: <https://cadenaser.com/emisora/2017/03/24/radio_madrid/1490353630_960294.html> (fecha de consulta: 23-06-2020).

9 «Un hombre se atrinchera con sus hijos y amenaza con quemar la casa». En: <https://www.elcorreo.com/bizkaia/sociedad/sucesos/201701/11/hombre-atrinchera-hijos-amenaza-20170111164049-rc.html> (fecha de consulta: 23-06-2020).

10 Este «Sexto rayograma» con un revólver y unas llaves sobre un papel fotográfico, se publicó en el álbum de Man Ray Les champs délicieux (1922), con prólogo de Tristan Tzara.

11 «La estafa de los padres de Nadia supera el millón de euros». En: <https://www.lavanguardia.com/sucesos/20170306/42573561379/estafa-padres-nadia-supera-millon-euros.html> (fecha de consulta: 23-06-2020).

12 ORTEGA, María, «Els Mossos desallotgen la casa okupada La Rimaia i detenen una dona». En: <https://www.ara.cat/societat/Mossos-dEsquadra-desallotgen-okupat-Rimaia_0_697130347.html> (fecha de consulta: 23-06-2020). 


\section{Bibliografía}

APHESBERO, Michelle y COLOMINE, Danielle (2003), «Evidence: natures mortes de la police, police still lives, bodegones policiales», en 4 Taxis, Special Issue, n. ${ }^{\circ} 21,22,23,24$.

ANDRÉ, Emmanuelle (2007), Esthétique du motif: cinéma, musique, peinture, Presses Universitaires de Vincennes, Saint-Denis. BALLÓ, Jordi y BERGALA, Alain (eds.) (2016), Los motivos visuales del cine, Galaxia Gutenberg, Barcelona.

BAUDRILLARD, Jean (1969), El sistema de los objetos, Siglo XXI, México.

BENJAMIN, Walter (1990), El origen del drama barroco alemán, Taurus, Madrid.

BERGER, John (2016), Modos de ver, Gustavo Gili, Barcelona.

BREDEKAMP, Horst (2007), «Las estrategias visuales de Thomas Hobbes» en SPRINGBORG, Patricia (ed.), The Cambridge companion to

Hobbe's Leviathan, Cambridge University Press, Cambridge, pp. 29-60.

BRYSON, Norman (2005), Volver a mirar. Cuatro ensayos sobre pinturas de naturalezas muertas, Alianza Editorial, Madrid.

BURKE, Peter (2005), Visto y no visto: el uso de la imagen como documento histórico, Editorial Crítica, Barcelona.

CALVO SERRALLER, Francisco (1999), El bodegón español. De Zurbarán a Picasso, Museo de Bellas Artes, Bilbao.

CALABRESE, Omar (1999), La era neobarroca, Ediciones Cátedra, Madrid.

CHERRY, Peter (1999), Arte y naturaleza: el bodegón español en el siglo de oro, Doce Calles, Aranjuez.

DE LA FLOR, Fernando R. (2009), Imago. La cultura visual y figurativa del Barroco, Abada Editores, Madrid.

DELEUZE, Gilles (1990), «Post-scriptum sur les sociétés de contrôle», Pourparlers 1972-1990, Les éditions de Minuit, París.

DIDI-HUBERMAN, Georges (2007), L'image ouverte: motifs de l'incarnation dans les arts visuels, Gallimard, París.

- (2009), La imagen superviviente. Historia del arte y tiempo de los fantasmas según Aby Warburg, Abada Editores, Madrid.

FOUCAULT, Michael (2012/1980), Vigilar y castigar: Nacimiento de la prisión, Siglo XXI, México.

GINZBURG, Carlo (2013), Peur révérence terreur. Quatre essais d'iconographie politique, Les Presses du réel, Dijon.

GUEVARA, Felipe de (1788), Comentarios de la pintura, Don Gerónimo Ortega, Hijos de lbarra y compañía, Madrid.

JORDAN, William (1985), Spanish still life in the golden age, 1600-1650, Kimbell Art Museum, Fort Worth.

LE BRETON, David (2003), Anthropologie du corps et modernité, PUF, París.

LOMBROSO, Gina (2006), Criminal Man, Combined Academic Publication, Londres.

MONEGAL, Antonio, RIDAO, José María y TORRES, Francesc (2004), En Guerra, Catálogo CCCB, Barcelona.

PACHECO, Francisco (1990), Arte de la pintura. Su antigüedad y grandezas, Cátedra, Madrid.

PANOFSKY, Erwin (1972), Estudios sobre iconología, Alianza Editorial, Madrid.

- (1964), Tomb Sculpture, four lectures on its changing aspects from ancient Egypt to Bernini, H. N. Abrams, Nueva York.

PÉREZ SÁNCHEZ, Alfonso (1983), Pintura española de bodegones y floreros de 1600 a Goya, Ministerio de Cultura, Madrid.

RAY, Man (1922), Les champs délicieux. Album de photographies, París.

SCHNEIDER, Norbert (2003), Naturaleza muerta. Apariencia real y sentido alegórico de las cosas. La naturaleza muerta en la edad moderna temprana, Taschen, Colonia.

STERLING, Charles (1959), La nature morte de l'antiquité a nos jours, Éditions Pierre Tisné, París.

STEYERL, Hito (2018), Los condenados de la pantalla, Cajanegra Editora, Buenos Aires.

SONTAG, Susan (2008), Sobre la fotografía, Random House Mondadori, Barcelona.

TAGG, John (1988), The Burden of Representation. Essays on Photography and Histories, University of Minnesota Press, Hong Kong.

VON SCHLOSSER, Julius (1988), Las cámaras artísticas y maravillosas del renacimiento tardío, Akal, Madrid.

WALKER, Michael (2005), Hitchcock's motifs, Amsterdam University Press, Amsterdam.

WIND, Edgar y GOMBRICH, Ernst (2019), Curiosa laboriosidad. Dos conferencias sobre Aby Warburg, Catálogo Libros, Santiago de Chile. 